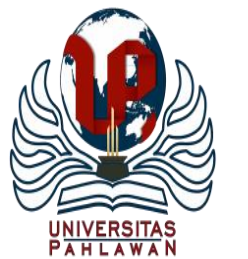

Edukatif : Jurnal Ilmu Pendidikan Volume 3 Nomor 1 Tahun 2021 Halm 261-268 EDUKATIF: JURNAL ILMU PENDIDIKAN

Research \& Learning in Education

https:/ledukatif.org/index.php/edukatif/index

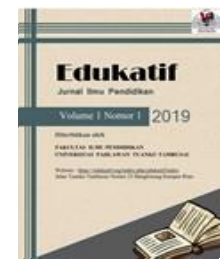

\title{
Media Pop Up Book Untuk Meningkatkan Hasil Belajar Siswa Pada Mata Pelajaran IPA Di Sekolah Dasar
}

\author{
Malfia Arip $^{1 凶}$, Hijrawatil Aswat ${ }^{2}$ \\ Universitas Muhammadiyah Buton, Baubau, Indonesia ${ }^{1,2}$ \\ E-mail : malfiaarip@ gmail.com ${ }^{1}, \underline{\text { hijrawatil171208@ gmail.com }}^{2}$
}

\begin{abstract}
Abstrak
Guru berperan sebagai kreator dalam proses belajar mengajar, yakni berperan sebagai orang yang mampu menciptakan kondisi pembelajaran yang baik, menarik, dan berdaya guna. Dalam proses belajar mengajar, media pembelajaran mempunyai peranan yang penting dalam suatu proses pembelajaran sehingga penelitian ini bertujuan untuk meningkatkan hasil belajar siswa pada mata pelajaran IPA menggunakan media pop up book. Jenis penelitian yang digunakan dalam penelitian ini adalah Penelitian Tindakan Kelas (PTK). PTK ini dilakukan melalui empat tahapan, yaitu perencanaan, pelaksanaan, observasi, dan refleksi. Penelitian ini dilakukan di SD Negeri 1 Lawela dengan subyek sebanyak 18 siswa. Instrumen yang digunakan dalam penelitian ini menggunakan lembar observasi guru untuk mengamati keterlaksanaan proses pembelajaran menggunakan media $P o p U p$ Book dan lembar observasi siswa untuk mengamati aktivitas belajar siswa, serta tes essay yang digunakan untuk melihat hasil belajar yang diperoleh siswa, setelah pelaksanaan pembelajaran telah dilakukan. Hasil penelitian ini menunjukkan bahwa penerapan pembelajaran dengan menggunakan media pop up book berhasil mencapai kriteria ketuntasan. Analisis data menunjukkan bahwa hasil belajar siswa dari rata-rata 68,3 pada siklus I meningkat menjadi 86,1 pada siklus II. Peningkatan juga terjadi pada tingkat ketuntasan siswa dimana pada siklus I sebanyak 50\% menjadi sebanyak $88,9 \%$ pada siklus II. Berdasarkan hasil penelitian, peneliti dapat menyimpulkan bahwa penerapan pembelajaran dengan menggunakan media pop up book dapat meningkatkan hasil belajar siswa pada mata pelajaran IPA, khususnya pada Tema 1 Organ Gerak Hewan dan Manusia, sehingga dapat disimpulkan bahwa penggunaan media Pop Up Book tepat digunakan pada mata pelajaran IPA khususnya materi organ gerak hewan dan manusia karena dapat menumbuhkan motivasi belajar siswa hingga berdampak pada hasil belajarnya.
\end{abstract}

Kata Kunci : Hasil belajar siswa, media pop up book

\begin{abstract}
A teacher acts as a creator in the teaching and learning process, namely acting as a person who is able to create learning atmosphere which is good, interesting, and efficient. Learning media has an important role in teaching and learning process, so this research aims to improve student learning outcomes in science subjects using pop up book media. The type of research used in this study is classroom action research (CAR). The research was carried out through four stages, namely planning, implementation, observation, and reflection. This research was conducted at SD Negeri 1 Lawela with subjects of 18 students. The instruments used in this study were teacher observation sheets to observe the implementation of the learning process using pop-up media, student observation sheets to observe students' learning activities, and essay tests used to see students' learning outcomes after the implementation of learning. The results of this study indicate that the application of learning using pop up media has succeeded in achieving completeness criteria. The data analysis show that students' learning outcomes from an average of 68.3 in the first cycle increased to 86.1 in the second cycle. The increase also occurs at the level of completeness of students where in the first cycle of $50 \%$ to $88.9 \%$ in the second cycle. Based on the results of the study, researchers can conclude that the application of learning using a pop up book media can improve students' learning outcomes in science subjects, especially in the theme of 1 animal and human movement organs, so that it can be concluded that the use of pop up books in science subjects especially on the material of animal and human movement organs is appropriate because it can foster students' learning motivation to have an impact on the learning outcomes.
\end{abstract}

Keywords : Students' learning outcomes, pop up book media

Copyright (c) 2021 Malfia Arip, Hijrawatil Aswat

$\triangle$ Corresponding author

Email : malfiaarip@gmail.com

DOI : https://doi.org/10.31004/edukatif.v3i1.329

ISSN 2656-8063 (Media Cetak) ISSN 2656-8071 (Media Online)

Edukatif : Jurnal Ilmu Pendidikan Vol 3 No 1 Tahun 2021 p-ISSN 2656-8063 e-ISSN 2656-8071 


\section{PENDAHULUAN}

Pendidikan merupakan proses yang kompleks, namun kompleksnya selalu seiring dengan perkembangan manusia. Dengan pendidikan pula berbagai aspek kehidupan dikembangkan melalui proses belajar dan distabilkan agar kondisi tercipta sesuai dengan tujuan yang ingin dicapai serta dapat diperoleh seoptimal mungkin. Sebagaimana yang dikemukakan oleh (Paul M. Muchinsky, 2012) pendidikan merupakan suatu proses yang mempunyai tujuan yang biasanya diusahakan untuk menciptakan pola-pola tingkah laku tertentu pada kanak-kanak atau orang yang sedang dididik. Guru berperan sebagai kreator dalam proses belajar mengajar, yakni berperan sebagai orang yang mampu menciptakan kondisi pembelajaran yang baik, menarik, dan berdaya guna. belajar menurut (Dewi, 2018) adalah suatu perubahan perilaku yang relatif permanen dan dihasilkan dari pengalaman masa lalu ataupun dari pembelajaran yang bertujuan atau direncanakan. dan Slameto, 2013 (Antara et al., 2014) mengartikan belajar ialah suatu proses usaha yang dilakukan seseorang untuk memperoleh suatu perubahan tingkah laku yang baru secara keseluruhan, sebagai hasil pengalamannya sendiri dalam interaksi dengan lingkungannya. Untuk melengkapi komponen belajar dan pembelajaran di sekolah, sudah seharusnya guru memanfaatkan media atau alat bantu yang mampu merangsang pembelajaran efektif dan efisien, yang didalamnya ditunjang oleh beberapa unsur pembelajaran antara lain tujuan pembelajaran, materi pembelajaran, sarana prasarana, situasi atau kondisi belajar, media pembelajaran, lingkungan belajar dan metode pembelajaran. Keberhasilan proses belajar mengajar dipengaruhi oleh semua unsur tersebut.

Proses belajar dikatakan berhasil apabila siswa dapat mencapai ketuntasan hasil belajar sesuai dengan standar yang telah ditetapkan. hasil belajar menurut Susanto (Naranjo, 2014) adalah perubahan-perubahan yang terjadi pada diri siswa, baik yang menyangkut aspek kognitif, afektif, dan psikomotor sebagai hasil dari kegiatan belajar. Sudjana (Wiratmaja, 2019) menekankan bahwa hasil belajar adalah perubahan perilaku secara keseluruhan bukan hanya salah satu aspek potensi kemanusiaan saja, artinya hasil pembelajaran tidak dilihat secara fragmentaris atau terpisah melainkan komprehensif. Secara sederhana, dapat disimpulkan bahwa yang dimaksud dengan hasil belajar adalah perubahan yang diperoleh siswa, dimana perubahan tersebut meliputi aspek kognitif, afektif, dan psikomotor setelah melalui kegiatan belajar.

Dalam proses belajar mengajar, media pembelajaran mempunyai peranan yang penting dalam suatu proses pembelajaran. Guru dituntut untuk dapat menggunakan media serta mampu membuat media pembelajaran yang dapat digunakan untuk menyalurkan pesan dari pengirim ke penerima pesan, sehingga dapat merangsang pikiran, perasaan, dan minat serta perhatian siswa dalam proses pembelajaran. Aqid 2013 (Sholeh, 2017), "Media pembelajaran adalah segala sesuatu yang dapat digunakan untuk menyampaikan pesan atau informasi dalam proses belajar mengajar sehingga dapat merangsang perhatian dan niat siswa dalam belajar". Hamalik (Dewanti et al., 2018) mengungkapkan bahwa penggunaan media dapat membantu proses pembelajaran lebih efektif, mempercepat proses pemahaman siswa terhadap materi pelajaran yang sedang dipelajarinya. Media pembelajaran adalah segala sesuatu yang digunakan oleh guru sebagai alat peraga untuk membantu dalam kegiatan belajar mengajar sehingga tujuan pembelajaran dapat tercapai. Penggunaan media dalam pembelajaran untuk menyampaikan pesan sehingga dapat merangsang siswa agar terjadi proses beajar. Apalagi bagi anak usia sekolah dasar yang perkembangan berfikirnya masih memerlukan sesuatu hal yang kongkret, belum merambah pada hal-hal yang sifatnya abstrak. Penggunaan media pembelajaran yang belum maksimal dapat berpengaruh dalam pelaksanaan suatu pembelajaran. Materi pelajaran yang disampaikan dengan menggunakan media lebih efektif daripada pembelajaran tanpa menggunakan media. Dengan media pembelajaran yang ada di sekolah, diharapkan siswa lebih tertarik untuk mempelajari pokok bahasan yang disampaikan sehingga dapat meningkatkan minat siswa dalam belajar serta pengalaman belajar siswa diharapkan bisa bertambah. Mata pelajaran IPA membutuhkan media dalam pengajarannya. Dengan materi yang berhubungan dengan makhluk hidup seperti manusia, hewan, dan tumbuh-tumbuhan, proses 


\section{Media Pop Up Book Untuk Meningkatkan Hasil Belajar Siswa Pada Mata Pelajaran IPA Di Sekolah Dasar-Malfia Arip, Hijrawatil Aswat \\ DOI: https://doi.org/10.31004/edukatif.v3i1.329}

pembelajarannya tidak akan berjalan dengan maksimal apabila materinya hanya dihadapkan dengan apa yang ada dalam buku ajar saja. Dalam pembelajaran, guru membutuhkan media yang tepat guna mempermudah siswa untuk memahami materi-materi yang ada dalam tiap mata pelajaran tersebut.

Media yang dapat digunakan untuk mengatasi permasalahan dalam pembelajaran IPA adalah media pop up book. Media pop up book menurut (Masturah et al., 2018) sangat praktis dan dapat menambah minat belajar siswa karena menvisualisasikan konsep belajar kedalam gambar tiga dimensi. Ann Montanaro (Masna, 2015) berpendapat bahwa sekilas pop up book hampir sama dengan origami dimana kedua seni ini mempergunakan teknik melipat kertas. Pinky (D \& Ardiansyah, 2019) mendefinisikan pop up book "sebagai suatu kartu yang terbuat dari kertas apabila dibuka dengan sudut tertentu $\left(90^{\circ}\right.$ dan $\left.180^{\circ}\right)$, maka akan memunculkan sebuah bentuk tampilan gambar yang timbul". Buku pop up memberikan visualisasi cerita yang lebih menarik. Buku ini juga memberikan kejutan-kejutan dalam setiap halamannya yang dapat mengundang ketakjuban ketika halamannya dibuka. Sehingga media pop up book diminati anak-anak karena memiliki daya Tarik dari segi pengemasan yang unik dan menarik, dengan sajian media tiga dimensi yang dapat menirukan objek tertentu (NAJAHAH, 2016). Selain itu, pop up book juga berfungsi untuk menambah daya ingat pada pelajaran, mengembangkan daya fantasi siswa dan menumbuhkan minat dan motivasi belajar. Pembelajaran yang dikemas dalam media pop up book akan memudahkan guru memberikan pemahaman kepada siswa terhadap pelajarannya dan menambah ketertarikan anak serta memicu kreatifitas anak setelah melihat objek tiruan, karena tersaji dalam bentuk tiga dimensi serta tampilan yang menarik dan menyerupai objek sesungguhnya namun dalam bentuk atau ukuran yang lebih kecil. Anak-anak akan merasa lebih senang dengan kejutan-kejutan yang dilihat dari setiap halamannya dimana gambar-gambar dapat timbul, berbeda dengan buku-buku cerita pada umumnya.

Permasalahan pembelajaran IPA masih terjadi di sekolah dasar. Berdasarkan pra penelitian yang dilakukan di SD Negeri 1 Lawela peneliti menemukan permasalahan dalam pelajaran IPA. Hal ini berdasarkan observasi dan wawancara dengan guru kelas V SD Negeri 1 Lawela diperoleh bahwa dalam proses pembelajaran, siswa kurang aktif dan tidak memperhatikan penjelasan guru. Selain itu guru hanya menggunakan media pembelajaran yang sudah tersedia di sekolah berupa buku paket. Hal tersebut mengakibatkan tingkat pemahaman siswa terhadap muatan IPA menjadi rendah dan berdampak pada hasil belajar yang rendah pula. Buku pelajaran yang digunakan dalam pembelajaran kurang menarik karena hanya berisi banyak tulisan dan beberapa gambar dan tebal sehingga mempunyai kesan membosankan dan monoton. Buku pelajaran dengan tampilan yang cenderung kurang menarik, menyebabkan kurangnya minat siswa untuk membaca buku. Selain itu, berdasarkan hasil tes awal yang telah dilakukan juga menunjukkan bahwa hanya terdapat 5 siswa $(27,7 \%)$ yang mendapatkan nilai yang memenuhi KKM yang ditetapkan yaitu 70 dan 13 siswa (72,3\%) mendapatkan nilai dibawah KKM. Data hasil belajar ditunjukkan dengan nilai terendah 20 dan nilai tertinggi 80. Dari data yang diperoleh, maka dapat disimpulkan bahwa pembelajaran IPA di kelas V SD Negeri 1 Lawela perlu ditingkatkan lagi kualitas proses pembelajarannya sehingga dapat meningkatkan hasil belajar siswa. Penelitian ini dilakukan guna mengatasi masalah belajar siswa dengan mendekatkan sumber belajar siswa secara kongkrit melalui media pop up book dengan mengajak siswa mengenali objek sasaran pembelajarannya melalui media yang unik dan menarik, selain itu siswa diajak untuk mendesain secara bersama medianya sehingga mengetahui alur makna dari objek yang dibentuknya. Berbeda dari penelitian sebelumnya yang hanya menampilkan sisi medianya secara langsung kepada siswa tanpa melibatkan siswa dalam memahami alur desain objek dan maksud dari objek yang dituju, sehingga memberikan pemahaman kepada siswa secara mendalam.

\section{METODE PENELITIAN}

Jenis penelitian yang digunakan adalah penelitian tindakan kelas. Peneliti bekerja sama dengan guru kelas V SD Negeri 1 Lawela dalam perencanaan, pelaksanaan, pengamatan dan refleksi untuk siklus 
selanjutnya. Aqib, 2011(Karso, 2019) menjelaskan bahwa Penelitian Tindakan Kelas (PTK) adalah penelitian yang dilakukan oleh guru di kelasnya sendiri melalui refleksi diri dengan tujuan untuk memperbaiki kinerjanya sehingga hasil belajar siswa meningkat. Dalam penelitian ini guru bertindak sebagai observer dan peneliti sebagai pelaksana kegiatan pembelajaran. Tekhnik pengumpulan data yang digunakan dalam penelitian ini adalah lembar observasi dan tes tertulis untuk melihat hasil belajar siswa. Setelah data diperoleh selanjutnya akan dilakukan analisis data untuk mengetahui tingkat pencapaian hasil belajar siswa selama proses belajar mengajar berlangsung. Dalam penelitian ini, hasil belajar siswa yang dikatakan meningkat jika hasil observasi dan tes yang diberikan telah mencapai KKM yang telah ditentukan, dimana KKM untuk pelajaran IPA adalah 70 dengan jumlah keseluruhan. Trianto (2010: 241) menyatakan bahwa setiap siswa dikatakan tuntas belajarnya (ketuntasan individu) jika proporsi jawaban benar siswa $>65 \%$, dan suatu kelas dikatakan tuntas belajarnya (ketuntasan klasikal) jika dalam kelas terdapat $>85 \%$ siswa yang telah tuntas belajarnya.

\section{HASIL DAN PEMBAHASAN PENELITIAN}

Perolehan data Penelitian Tindakan Kelas (PTK) ini berasal dari siswa kelas V SD Negeri 1 Lawela Kabupaten Buton Selatan. Penelitian ini dilakukan mulai dari tahap pra siklus, siklus I, dan siklus II. sebelum melaksanakan tindakan siklus I, peneliti melakukan tes pra siklus terlebih dahulu. Tes pra siklus terdiri dari 10 soal isian dengan bobot nilai 10 poin per nomor jika siswa menjawab dengan benar dan 0 poin jika siswa menjawab salah atau tidak menjawab. Tes pra siklus diikuti oleh 18 siswa, terdiri dari 10 siswa laki-laki dan 8 siswa perempuan. Tes pra siklus dilaksanakan untuk mengetahui keadaan awal hasil belajar siswa sebelum melakukan tidakan siklus. Adapun rekapitulasi tes pra siklus menunjukkan bahwa dari jumlah keseluruhan 18 siswa, hanya 5 siswa yang dinyatakan tuntas dalam hasil belajarnya, sedangkan ada 13 siswa yang tidak tuntas.Dari hasil tes awal dapat disimpulkan bahwa hasil belajar awal siswa masih rendah, sehingga perlu dilakukan pembelajaran yang lebih baik pada siklus I. Dengan ini, peneliti melakukan perbaikan pembelajaran dengan melanjutkan pada siklus I menggunakan media Pop Up Book pada materi Organ Gerak Hewan dan Manusia.

Hasil evaluasi siswa mengalami peningkatan dari siklus I ke siklus II. Adapun perbandingkan hasil evaluasi pada siklus I dan siklus II dapat dilihat pada tabel berikut:

Tabel 1

Perbandingan Hasil Belajar Siswa pada Siklus I dan Siklus II

\begin{tabular}{|c|c|c|c|c|c|c|}
\hline No & Skor & Kategori & $\begin{array}{c}\text { Frekuensi } \\
\text { Siklus I }\end{array}$ & $\begin{array}{c}\%) \\
\text { Siklus } \\
\text { I }\end{array}$ & $\begin{array}{c}\text { Frekuensi } \\
\text { Siklus II }\end{array}$ & $\begin{array}{c}(\%) \\
\text { Siklus } \\
\text { II }\end{array}$ \\
\hline 1 & $85-100$ & $\begin{array}{l}\text { Sangat } \\
\text { Tinggi }\end{array}$ & 5 & $27,8 \%$ & 8 & $44,45 \%$ \\
\hline 2 & $70-84$ & Tinggi & 4 & $22,2 \%$ & 8 & $44,45 \%$ \\
\hline 3 & $60-69$ & Cukup & 3 & $16,7 \%$ & 2 & $11,1 \%$ \\
\hline 4 & $51-59$ & Rendah & - & - & - & - \\
\hline 5 & $0-50$ & $\begin{array}{l}\text { Sangat } \\
\text { Rendah }\end{array}$ & 6 & $33,3 \%$ & - & - \\
\hline & \multicolumn{2}{|c|}{ Jumlah } & 18 siswa & $100 \%$ & 18 siswa & $100 \%$ \\
\hline & \multicolumn{2}{|c|}{ Skor Tertinggi } & 100 & & 100 & \\
\hline & \multicolumn{2}{|c|}{ Skor Terendah } & 30 & & 60 & \\
\hline & \multicolumn{2}{|c|}{ Rata-Rata } & 68,3 & & 86,1 & \\
\hline
\end{tabular}


Dari hasil tes akhir siklus I tersebut, hasil belajar siswa mengalami peningkatan dibandingkan dengan hasil tes pra siklus, namun persentase ketuntasan belajar siswa masih dibawah kriteria ketuntasan yang diharapkan yaitu $85 \%$ dari jumlah siswa yang mengikuti tes. Dengan demikian masih diperlukan siklus berikutnya untuk membuktikan bahwa penerapan pembelajaran menggunakan media Pop Up Book mampu meningkatkan hasil belajar siswa kelas V SD Negeri 1 Lawela. Tabel nilai siswa di atas menunjukan bahwa hasil belajar siswa mengalami peningkatan dari Siklus I ke Siklus II, terbukti dari nilai rata-rata kelas siklus II yaitu 86,1 yang lebih baik dari nilai rata-rata kelas siklus I sebelumnya yaitu 68,3.Adapun persentase ketuntasan hasil belajar siswa dapat diketahui bahwa dari sejumlah 18 siswa yang melakukan evaluasi siklus II terdapat 16 siswa atau $88,9 \%$ telah mencapai nilai $\mathrm{KKM}$ dengan nilai $\geq 70$ dan dinyatakan tuntas. Sedangkan 2 siswa lainnya atau $11,1 \%$ belum mencapai batas ketuntasan yang telah ditetapkan dengan nilai $<70$. Dari hasil tes akhir siklus II tersebut, hasil belajar siswa mengalami peningkatan dibandingkan dengan hasil tes siklus I. Berdasarkan persentase ketuntasan belajar dapat diketahui bahwa pada siklus II siswa kelas V SD Negeri 1 Lawela sudah memenuhi kriteria ketuntasan belajar yaitu $85 \%$ dari jumlah siswa yang mengikuti tes. Dengan demikian penelitian tindakan kelas ini dihentikan pada siklus II.

Berdasarkan hasil observasi dan evaluasi yang diisi oleh siswa dapat disimpulkan bahwa guru telah mampu mempertahankan dan meningkatkan pelaksanaan kegiatan belajar mengajar dengan menggunakan media pembelajaran Pop Up Book. Dengan melibatkan siswa secara langsung mendesain dan membentuk medianya sehingga dapat menggali pemahaman siswa dan rasa ingin tahu siswa terhadap objek pembelajarannya. Hal ini didasarkan pada hasil observasi yang menunjukkan peningkatan dengan semakin membaiknya kegiatan belajar mengajar berdasarkan pengamatan observer dan juga hasil evaluasi siswa mengalami peningkatan. Hal ini dapat dilihat dari peningkatan persentase ketuntasan belajar siswa yaitudari 50\% pada siklus I meningkat menjadi 88,9\% pada siklus II. Dapat disimpulkan bahwa persentase hasil belajar siswa dengan menggunakan media Pop Up Book pada siklus II mengalami penigkatan sebesar 33,9\%.Dengan demikian, berdasarkan hasil belajar pada siklus II rata- rata hasil belajar IPA siswa pada materi Organ Gerak Hewan dan Manusia yaitu hasil tersebut telah sesuai dengan target yang ingin dicapai. Karena tingkat hasil belajar sudah tercapai, maka guru tidak melanjutkan ke siklus berikutnya. Hasil menunjukkan bahwa pelaksanaan pembelajaran dengan menggunakan media Pop Up Book dapat meningkatkan hasil belajar siswa.

Penerapan media Pop Up Book dalam proses pembelajaran yang dilaksanakan peneliti telah terlaksana dengan optimal. Pembelajaran menggunakan media Pop Up Book jika dikaitkan dengan materi Organ Gerak Hewan dan Manusia dinyatakan sudah maksimal. Hal ini ditandai dengan indikator yang terdapat pada lembar observasi guru dan siswa sudah terlaksana dengan baik. Dalam proses pembelajaran, aktivitas guru diamati dimana peneliti bertindak sebagai guru yang diamati dengan menggunakan lembar observasi yang diisi oleh wali kelas sebagai observer. Dari hasil observasi, diketahui bahwa guru telah mampu mengkondusifkan kelas sehingga siswa dapat terkontrol dengan baik. Sedangkan dalam menggali materi yang dipelajari, siswa telah mampu menemukan dan menerapkan idenya sendiri melalui keterlibatan aktif dalam mendesain dan Menyusun media pop up book menjadi media yang dapat memperagakan organ gerak hewan dan manusia dalam proses belajar mengajar. Pada saat sebelum dilakukan tindakan keaktifan siswa masih kurang, hal ini dikarenakan sebagian besar proses pembelajaran masih dikuasai oleh guru dan guru belum menggunakan media pembelajaran. Setelah dilakukan tindakan hasilnya mulai ada peningkatan. Pada siklus I keaktifan siswa mulai terlihat, meskipun yang aktif sebagian besar adalah siswa yang mempunyai keberanian, namun pada siklus II guru merencanakan untuk mengaktifkan siswa yang belum berani dengan memberikan kesempatan untuk bertanya dan menjawab pertanyaan-pertanyaan yang diajukan guru dan siswa lainnya sehingga siswa lebih aktif dan meningkat secara merata. Dan dalam hal bertanya, siswa sudah mulai terbiasa mengajukan pertanyaan kepada guru. Selain itu, melalui penggunaan media pembelajaran Pop Up Book dalam mengajarkan materi Organ Gerak Hewan dan Manusia juga dapat meningkatkan hasil belajar siswa yang telah ditentukan. 
Meningkatnya aktivitas guru dan aktivitas siswa juga membuat hasil belajar siswa dari siklus I sampai siklus II dapat meningkat. Dari hasil penelitian yang telah dibahas sebelumnya menunjukkan bahwa jika belajar menggunakan media Pop Up Book pada materi Organ Gerak Hewan dan Manusia, hasil belajar siswa dari pra siklus sampai siklus II semakin meningkat. Hal ini dapat dilihat dari hasil tes evaluasi yang telah dilakukan oleh peneliti. Pada pra siklus atau tes awal dilakukan untuk mengetahui sejauh mana pengetahuan siswa tentang pembelajaran IPA khususnya pada materi Organ Gerak Hewan dan Manusia. Setelah melakukan tes pra siklus yang diikuti oleh 18 siswa, diketahui hanya 5 siswa atau 27,7\% yang dapat dinyatakan tuntas, sedangkan 13 siswa lainnya atau 72,3\% dinyatakan tidak tuntas dengan nilai rata-rata 53,9. Dengan ini, maka peneliti melaksanakan perbaikan pada berbagai aspek proses pembelajaran IPA terutama dalam proses pembelajaran materi Organ Gerak Hewan dan Manusia. Sesuai rencana awal, Setelah dilakukannya tes evaluasi pada siklus I terdapat beberapa aspek yang belum terlaksana dengan baik. Dengan demikian peneliti memperbaiki proses belajar mengajar dengan membimbing dan memberikan motivasi yang lebih kepada siswa agar siswa bisa belajar lebih aktif. Pada siklus I siswa yang memiliki nilai tuntas meningkat sebanyak 9 siswa atau 50\% dinyatakan, sedangkan 9 siswa lainnya atau 50\% dinyatakan tidak tuntas dengan nilai rata-rata 68,3. Dengan ini, maka peneliti melanjutkan penelitian ke siklus II dengan perbaikan di berbagai aspek.

Pada tindakan siklus II merupakan perbaikan pembelajaran yang dilaksanakan pada siklus I. Guru dapat lebih mudah membimbing siswa karena motivasi dan antusias siswa dalam belajar lebih baik lagi dibandingkan dengan siklus I, guru juga lebih memfokuskan dan memberikan perhatian lebih kepada siswa yang kurang aktif dalam bertanya dan mengemukakan pendapatnya, siswa yang tidak fokus dalam belajar serta kepada siswa yang belum tuntas hasil belajar pada siklus sebelumnya. Setelah dilakukan tes evaluasi pada siklus II, nilai siswa sudah banyak yang meningkat namun masih ada 2 siswa yang belum tuntas. Pada siklus II siswa yang memliki nilai tuntas sebanyak 16 siswa atau 88,9\%, sedangkan siswa yang memiliki nilai tidak tuntas sebanyak 2 siswa atau 11,1\% dengan nilai rata-rata 86,1. Dengan ini peneliti tidak melanjutkan penelitian ke siklus berikutnya dikarenakan persentase ketuntasan hasil belajar siswa sudah mencapai 88,9\% dan sudah melampaui target dari indikator keberhasilan tindakan yaitu $85 \%$. Lebih jelasnya peningkatan hasil belajar siswa dapat dilihat pada grafik persentase ketuntasan saat pra siklus, siklus I, dan siklus II berikut:

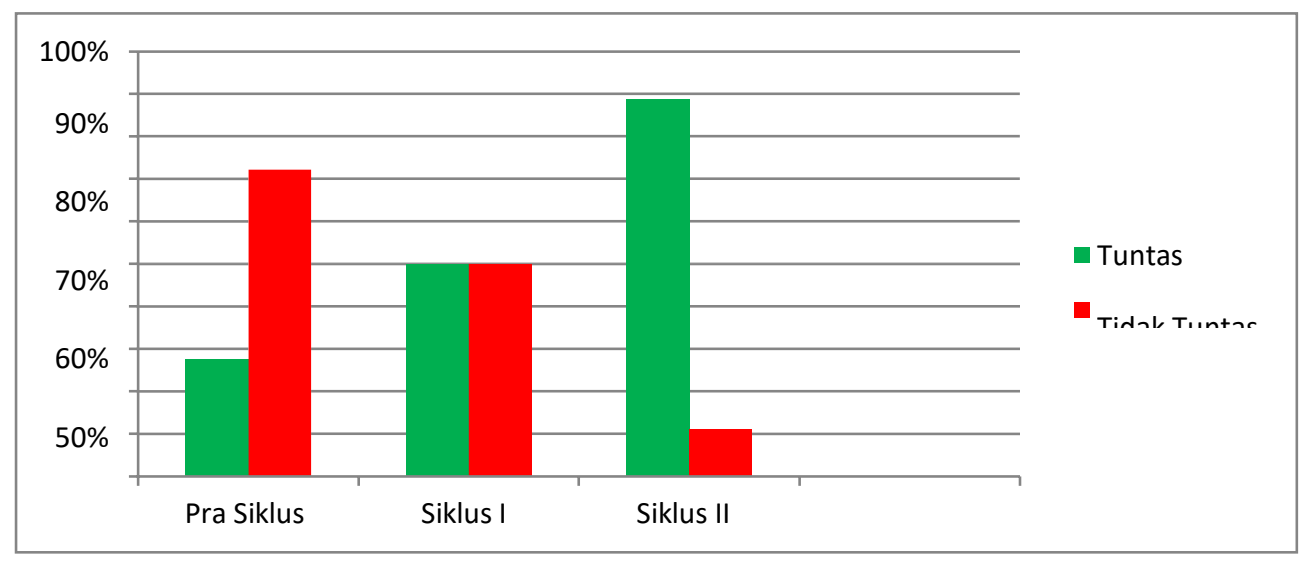

Gambar 1. Grafik Ketuntasan Belajar Siswa

Grafik di atas menunjukkan bahwa adanya peningkatan hasil belajar siswa yang tuntas belajar pada pra siklus sejumlah 27,7\% (5 siswa) sedangkan siswa yang tidak tuntas sejumlah 72,3\% (13 siswa), kemudian siswa yang tuntas pada siklus I sejumlah 50\% (9 siswa) sedangkan yang tidak tuntas sejumlah 50\% (9 siswa), dan pada siklus II sejumlah 88,9\% (16 siswa) sedangkan yang tidak tuntas sejumlah 11,1\% (2 siswa).

Dari data ketuntasan belajar siswa pada siklus II masih terdapat siswa yang memiliki nilai tidak tuntas. Setelah diamati, faktor penyebab rendahnya hasil belajar siswa tersebut yaitu kurangnya minat mereka untuk belajar IPA sehingga mereka kurang berkonsentrasi dan kurang fokus pada materi yang sedang diajarkan. 
Namun, fakta tersebut tidaklah berpengaruh kepada ketuntasan belajar siswa. Dengan lebih banyaknya siswa yang tuntas belajar, maka target yang diharapkan pun telah tercapai. Dengan demikian, diambil kesimpulan bahwa penggunaan media Pop Up Book dapat meningkatkan hasil belajar siswa pada mata pelajaran IPA. Dan meningkatkan kreatifitas siswa dalam mendesain dan membentuk objek sasaran pembelajarannya. Dalam hal ini siswa dilibatkan dalam membuat media organ gerak hewan dan manusia, sehingga siswa memahami dan dapat membentuk konsep dasar pemahamannya terhadap objek sasaran. Berbeda dengan penelitianpenelitian sebelumnya dimana media pop up book disediakan atau dibuat sendiri oleh guru dan disajikan di kelas, sedangkan dalam penelitian ini guru mengajak siswa untuk membentuk objek sasarannya dalam buku tiga dimensi atau timbul yang dapat merangsang pengetahuan awal siswa terhadap objek pembelajarannya.

\section{KESIMPULAN}

Dalam proses pembelajaran, media Pop Up Book digunakan pada siklus I dan siklus II. Pada siklus I, penggunaan media Pop Up Book pelajaran IPA dapat meningkatkan hasil belajar siswa dari nilai rata-rata siswa 53,9 menjadi 68,3 dengan peningkatan rata-rata 14,4. Kemudian pada siklus II, nilai rata-rata siswa meningkat lagi menjadi 86,1 dengan peningkatan rata- rata 17,8 dan ketuntasan $88,9 \%$. Nilai tersebut sudah mencapai KKM dan telah mencapai target dimana lebih dari $85 \%$ siswa memperoleh nilai $\geq 70$.Dengan ini, maka dapat disimpulkan bahwa dengan menggunakan media Pop Up Book dapat meningkatkan hasil belajar siswa pada mata pelajaran IPA Tema 1 Organ Gerak Hewan dan Manusia di kelas V SD Negeri 1 Lawela Kabupaten Buton Selatan.

Berdasarkan hasil penelitian, peneliti menyampaikan saran Bagi guru, diharapkan penelitian ini dapat digunakan sebagai bahan informasi untuk upaya meningkatkan dan menambah pengetahuan serta keahlian dan kreativitas dalam menggunakan media pembelajaran yang efektif dan efisien. Bagi sekolah, diharapkan penelitian ini dapat memberikan kontribusi bagi pengembangan pembelajaran IPA di SD Negeri 1 Lawela khususnya dalam pengembangan dan pemanfaatan media pembelajaran.Bagi peneliti lain, diharapkan penelitian ini dapat menambah literature peneliti dalam mengajar, mengimplementasikan sebuah media, dan melatih peneliti unutk belajar memecahkan masalah yang ada di sekolah secara langsung.Kepada siswa agar selalu memacu diri untuk tetap mengulangi materi pelajaran baik yang sudah diberikan sebelumnya maupun materi yang akan diajarkan pada pertemuan berikutnya.

\section{UCAPAN TERIMA KASIH}

Terimakasih kepada Rekor Universitas Muhammadiyah Buton (UM Buton), Dekan Fakultas Keguruan dan Ilmu Pendidikan (FKIP) Universitas Muhammadiyah Buton dan Ketua Program Studi Pendidikan Guru Sekolah Dasat FKIP UM Buton yang sudah mendukung dan memfasilitasi penulis sehingga artikel ini dapat terselesaikan. Terimakasih kepada Tim Jurnal Ilmu Pendidikan yang sudah bersedia menerima artikel ini untuk diterbitkan.

\section{DAFTAR RUJUKAN}

Antara, I. N. R., Haris, I. A., \& Nuridja, I. M. (2014). Pengaruh Kesiapan dan Transfer Belajar Terhadap Hasil Belajar Ekonomi di SMA Negeri 1 Ubud. Jurnal Pendidikan Ekonomi Undhiska, 4(1), 1-12.

D, D. A., \& Ardiansyah, B. F. (2019). Analisis Teknik Dan Perkembangan Buku Pop-Up. Narada: Jurnal Desain Dan Seni, 6(1), 129. https://doi.org/10.22441/narada.2019.v6.i1.007

Dewanti, H., Toenlioe, A. J. E., \& Soepriyanto, Y. (2018). Pengembangan media Pop-Up Book untuk Pembelajaran Lingkungan Tempat Tinggalku Kelas IV SDN 1 Pakuaden Kabupaten Ponorogo. Jurnal Kajian Teknologi Pendidikan, 1(3), 221-228. http://journal2.um.ac.id/index.php/jktp/article/viewFile/4551/3408

Dewi, E. R. (2018). Metode Pembelajaran Modern Dan Konvensional Pada Sekolah Menengah Atas. 
268 Media Pop Up Book Untuk Meningkatkan Hasil Belajar Siswa Pada Mata Pelajaran IPA Di Sekolah Dasar-Malfia Arip, Hijrawatil Aswat

DOI: https://doi.org/10.31004/edukatif.v3i1.329

PEMBELAJAR: Jurnal Ilmu Pendidikan, Keguruan, Dan Pembelajaran, 2(1), 44. https://doi.org/10.26858/pembelajar.v2i1.5442

Karso. (2019). Keteladanan Guru dalam Proses Pendidikan di Sekolah. Prosiding Seminar Nasional Pendidikan Program Pascasarjana Universitas PGRI Palembang, 12 Januari 2019, 2, 382-397.

Masna, A. A. (2015). Pengembangan Bahan Ajar Pop-Up Mata Pelajaran IPA Untuk Anak Tunarungu Kelas IV SDLB B di Yogyakarta. Universitas Negeri Yogyakarta.

Masturah, E. D., Mahadewi, L. P. P., \& Simamora, A. H. (2018). Pengembangan Media Pembelajaran Pop-Up Book pada Mata Pelajaran IPA Kelas III Sekolah Dasar. Jurnal EDUTECH Universitas Pendidikan Ganesha, 6(2), 212-221.

NAJAHAH, I. (2016). Perancangan Buku Pop-Up Sebagai Media Pembelajaran Tentang Rumah Dan Pakaian Adat Nusantara Di Jawa. Jurnal Seni Rupa, 4(03), 494-501.

Naranjo, J. (2014). Peningkatan Hasil Belajar Siswa Pada Pembelajaran Ipa Menggunakan Metode Pengalaman Langsung Kelas Iv. Applied Microbiology and Biotechnology, 85(1), 2071-2079.

Paul M. Muchinsky. (2012). Inovasi Pendidikan Suatu Analisis Terhadap Kebijakan baru Pendidikan. In Psychology Applied to Work: An Introduction to Industrial and Organizational Psychology, Tenth Edition Paul (Vol. 53, Issue 9).

Sholeh, M. (2017). Pengembangan Media Pop-Up Book Berbasis Budaya Lokal Sub Tema Keberagaman Budaya Bangsaku Siswa Kelas Iv Sekolah Dasar Skripsi. Artikel Ilmiah, 1-15.

Wiratmaja, C. G. A. (2019). Penerapan Model Pembelajaran Kooperatif Tipe Jigsaw Untuk Meningkatkan Hasil Belajar Fisika Siswa. Jurnal Santiaji Pendidikan (JSP), 9(2), 127-133. https://doi.org/10.36733/jsp.v9i2.393 